\title{
Genetic Diversity and Inbreeding Level of Cotoneaster orbicularis Schltdl. in The Sinai Mountains Revealed by Microsatellite Markers and Flow Cytometry
}

\author{
H. Mansour ${ }^{1,2 \#}$ and Elwira Sliwinska ${ }^{3}$ \\ ${ }^{1}$ Biological Sciences Department, Rabigh-College of Science \& Arts, King Abdulaziz University, \\ Rabigh 21911, Saudi Arabia; ' Department of Botany, Faculty of Science, Suez Canal University, \\ Ismailia, 41522 Egypt and ${ }^{3}$ Laboratory of Molecular Biology and Cytometry, Department of Plant \\ Genetics, Physiology and Biotechnology, UTP University of Science and Technology, Kaliskiego \\ Ave. 7, 85-789 Bydgoszcz, Poland
}

COTONEASTER orbicularis Schltdl, native to Egypt and the eastern part of the Arab
peninsula, is an endangered species and the surviving individuals are dispersed in the
mountains of South Sinai, Egypt. Several threats, including habitat aridification and the impact of
human interference have caused a noticeable reduction in population size and number. Analyzing
the genetic diversity and mating system of $C$. orbicularis is crucial for its conservation and
management. In this study, six polymorphic microsatellite markers, formerly developed as
species-specific markers, were used to assess the genetic variability and extent of inbreeding
in the $C$. orbicularis populations. Flow cytometry of seeds was used to establish genome size.
Low total heterozygosity $\left(H_{T}=0.464\right)$ for all loci and populations, high differentiation between
populations $\left(F_{S T}=0.634, R_{S T}=0.889\right)$, and high levels of inbreeding $(F=0.906)$ were found.
Most of the embryos possessed about $1.9 \mathrm{pg} / 2 \mathrm{C}$ DNA; however, embryos with $3.8 \mathrm{pg} / 2 \mathrm{C} \mathrm{DNA}$
also occurred. The results provide markers that can be used in the management of conservation,
including habitat recovery and ex-situ conservation, in order to prevent extinction.

Keywords : Genetic diversity, Cotoneaster orbicularis, Microsatellite, DNA content, Mating system

\section{Introduction}

The genus Cotoneaster Medik. (Maloideae: Rosaceae), includes approximately 90 species, mainly distributed in Europe, temperate regions of Asia and Northern Africa. Numerous Cotoneaster species have become well-known ornamentals because of their desirable appearance (Dickoré \& Kasperek, 2010). Egypt's only species in this genus and also one of the rarest plants in the country is Cotoneaster orbicularis Schltdl. Its distribution is restricted to the mountainous South Sinai, east of Arabia. It grows in crevices of smooth-faced rocky outcrops and in soft dykes (El Hadidi, 1991). It is traditionally well known in folk medicine for their antiviral, antitumor, and diuretic properties (Bolous, 1983), and a source of novel phenolic glycosides (El-Mousallamy et al., 2000)

C. orbicularis inhabits six sites on high elevated slopes and terraces of mountains in the Saint Catherine region, South Sinai (above 1700 $\mathrm{m})$. Populations contain a very low number of individuals, ranging from 14 to 38 adult plants.
The rarity of $C$. orbicularis and its challenging reduction in population size is apparently caused by increasing aridity of its habitat (Grainger, 2003). Anthropogenic effects, in addition to climate change (Giorgi \& Lionello, 2008 and Issar, 2008), predict an even greater collapse in the size of its populations. Another constraint on the persistence of $C$. orbicularis is apomictic reproduction, which is typical for the majority of Cotoneaster species. Of about 450 putative species studied by Hylmö \& Fryer (1999), less than 5\% produced variable offspring and therefore appear to be sexually produced. In line with other plant genera where apomixis occurs, the apomictic Cotoneaster species seem to be polyploid whereas the sexualreproducing species are diploid (Hylmö \& Fryer, 1999). Frequently, small population sizes and rare gene flow within fragmented populations cause substantial inbreeding in a species and therefore deficient genetic diversity (Hansson \& Westerberg, 2002; Frankham, 2005 and Jump et al., 2009). Inbreeding and low genetic diversity may limit the potential of a species to adapt to altering environmental conditions, subsequently leading to its extinction (Heller \& Zavaleta, 2009).

\footnotetext{
\#Corresponding author email : hassan_mansour@science.suez.edu.eg Telephone: +201222795225. 
Accordingly, there is a necessity for an adequate assessment of the genetic variability and levels of inbreeding in $C$. orbicularis, as these data are crucial for the design of dynamic management strategies for the safeguarding of such rare species (Frankham et al., 2002).

The present study aims to provide information that can be used to determine the nature of C. orbicularis conservation programs. The objectives were to: (i) Quantify the genetic variability and genetic structure of $C$. orbicularis populations; (ii) Estimate the mating systems in natural populations of $C$. orbicularis; (iii) Determine nuclear DNA content (ploidy). All existing populations of $C$. orbicularis were sampled and the genetic diversity was evaluated by simple sequence repeats (SSR) analysis utilizing a group of six novel microsatellite loci (Mansour et al., 2016), since these are considered to be appropriate for revealing genetic variation even within severely rare and endemic species (Mansour et al., 2013). Nuclear DNA content was estimated by flow cytometry; the genome size for this species is reported for the first time.

\section{Materials and Methods}

\section{Plant material}

Six populations of $C$. orbicularis were sampled in the mountains and valleys of the Saint Katherine region, Egypt (Fig. 1), in the late summer 2014. The largest population sampled, Gebel Um Louz (UL), with 38 observed individuals was found in a crevice of smooth-faced rocky outcrops in a highly rugged area of Um Louz Mountain. Populations Al Qalaa (AQ), Nehaza Um Louz (NUL), Shqif Abu Shawht (SAS) were found in the same region, Wadi Gebal, east of the UL population at a distance of at least 1 kilometer from each other. The populations were of similar size with 20, 28, and 27 individuals, respectively. The Wadi Mezah (WM) population, consisting of 17 individuals, is located at a moderate slope hill west of the UL population. The smallest population, Wadi Shaq Mousa region (ShaMo), is located in a mountainous incision on the shaded base back of rocks and boulders, where only 14 individuals could be counted during our sampling. Ten plants per population were analyzed by microsatellite markers. In total, 60 individuals were analyzed, which represented $41 \%$ of the 144 detectable plants of $C$. orbicularis. One to three green leaflets per individual were collected and preserved dry on silica gel until DNA extraction. Seeds for flow cytometry were collected from three populations only, ShaMo, UL, WM, because they were not set in three remaining populations.

\section{Genomic DNA isolation and PCR amplification}

The isolation of genomic DNA was carried out using dried leaves with the DNeasy Plant Mini Kit, Qiagen. For each individual ten loci: Cor31, Cor35, and Cor36, Cor40, Cor41, Cor42, Cor43, Cor44, Cor53, and Cor54 were developed previously for $C$. orbicularis by Mansour et al., (2016) and tested for polymorphism; six loci exhibited polymorphism: Cor36, Cor40, Cor42, Cor44, Cor53, and Cor54 (Table 1). PCR was performed in a total volume $25 \mu \mathrm{l}$ containing 2.5 $\mu \mathrm{l}$ of $10 \times$ reaction buffer $\left(1 \mu \mathrm{l} \mathrm{MgCl}^{2}(50 \mathrm{mM})\right.$, $0.5 \mu \mathrm{l}$ of a mix of all $4 \mathrm{dNTPs}(10 \mathrm{mM}$ each), $0.2 \mu$ f forward primer including the M13-tail (10 $\mu \mathrm{M}), 0.5 \mu \mathrm{l}$ reverse primer $(10 \mu \mathrm{M}), 0.5 \mu \mathrm{l}$ of the universal M13 primer $(10 \mu \mathrm{M})$ labeled with a fluorophore (FAM, NED, VIC, or PET), $0.1 \mu \mathrm{l}$ Taq DNA polymerase (Dream Tag, Fermentas; 50 $\mathrm{U} / \mu \mathrm{l}), 1.0 \mu \mathrm{l}$ bovine serum albumin $(20 \mathrm{mg} / \mathrm{ml})$, $1.0 \mu \mathrm{l}$ of $10 \mathrm{ng} / \mu \mathrm{l}$ genomic DNA, and sterilized water up to a final volume of $25 \mu \mathrm{l}$. All PCR reactions were performed in singleplexes using a C1000 Thermal Cycler (BioRad, USA) under the following conditions: initial denaturation at $94^{\circ} \mathrm{C}$ for $3 \mathrm{~min}, 40$ cycles at $94^{\circ} \mathrm{C}$ for 30 seconds, $55^{\circ} \mathrm{C}$ for 45 seconds and $72^{\circ} \mathrm{C}$ for 1 min, 8 cycles at $94^{\circ} \mathrm{C}$ for $30 \mathrm{sec}, 53^{\circ} \mathrm{C}$ for $45 \mathrm{sec}, 72^{\circ} \mathrm{C}$ for 1 min, and a final extension step at $72^{\circ} \mathrm{C}$ for $5 \mathrm{~min}$. The resulting fluorescently labeled PCR products were analysed in multiplexes on a 3130xl Genetic Analyzer (Applied Biosystems, Foster City, CA, USA) using LIZ500 (Applied Biosystems, USA) as a size standard. The amplified fragments were scored using GeneMapper 4.0 (Applied Biosystems, USA), according to Arif et al.(2010).

\section{Analysis of genetic variation and mating system}

Genetic variation in $C$. orbicularis was analyzed by determining the number of alleles per locus $(A)$ and the total heterozygosity $\left(H_{\mathrm{T}}\right.$; used as measurement for total genetic diversity). Genetic differentiation among populations was tested with $F_{\mathrm{ST}}$ (Weir \& Cockerham, 1984) and $R_{\mathrm{ST}}$, an analogue of $F_{\mathrm{ST}}$ developed for microsatellite loci (Slatkin, 1995). An analysis of molecular variance (AMOVA; 999 permutations) was used to estimate the population genetic structure of $C$. orbicularis (Excoffier et al., 1992 and Michalakis $\&$ Excoffier, 1996). The number of reproductively 
successful migrants per generation $(\mathrm{Nm})$ was calculated using the private allele method (Barton \& Slatkin, 1986). The established heterozygosity $\left(H_{\mathrm{o}}\right)$, expected heterozygosity $\left(H_{\mathrm{e}}\right)$ under HardyWeinberg equilibrium, and Wright's, (1943) fixation index $F=1-H_{\mathrm{o}} / H_{\mathrm{e}}$ were assessed for each locus in each population to test deviations from the Hardy-Weinberg equilibrium, which determine inbreeding. Chi-squared tests were applied to determine the concordance of genotype frequencies with Hardy-Weinberg equilibrium. All analyses were evaluated using GenAlEx 6.1 (Peakall \& Smouse, 2006), except for $H_{\mathrm{T}}$, which was calculated according to Nei (1973), and considered for the number of individuals per population.

In addition, the mating system of $C$. orbicularis was assessed by calculating multilocus $\left(t_{\mathrm{m}}\right)$ and single-locus $\left(t_{\mathrm{s}}\right)$ outcrossing rates of the six sampled populations. Inbreeding in plant populations might arise from either selfing and/ or mating with close relatives (i.e., biparental inbreeding). The level of biparental inbreeding was estimated by calculating the difference between the multilocus outcrossing rate $t_{\mathrm{m}}$ and the singlelocus outcrossing rate $t_{\mathrm{s}}$ (Ritland, 2002) for all six microsatellite loci. Positive values of this difference indicate biparental inbreeding. These analyses were performed using the multilocus mating system program MLTR version 3 for Windows (Ritland 2004), which implements the maximum likelihood methods developed by Ritland \& Jain (1981) and Ritland (2002).

\section{Flow cytometry}

For flow cytometric analysis true seeds were isolated from the Marie \& Brown (1993)fruits. Many fruits were empty or contained degenerated seeds, which limited the number of analyzed individuals. A single embryo of $C$. orbicularis and a fragment of the leaf of an internal standard (Petunia hybrida $\mathrm{P} \times \mathrm{Pc} 6,2.85 \mathrm{pg} / 2 \mathrm{C}$;) were chopped simultaneously in a Petri dish containing $1 \mathrm{ml}$ Galbraith's buffer (Galbraith, et al. 1983), supplemented with propidium iodide (PI; $50 \mu \mathrm{g} /$ $\mathrm{ml})$ and ribonuclease $\mathrm{A}(50 \mu \mathrm{g} / \mathrm{ml})$. After chopping, the suspension was passed through a $50 \mu \mathrm{m}$ mesh nylon filter. For each sample, 5000-7000 nuclei were analysed after incubation of the sample for 20-30 min on ice, using a CyFlow SL (Partec $\mathrm{GmbH}$, Münster, Germany) flow cytometer equipped with a high-grade solid-state laser with green light emission at $532 \mathrm{~nm}$, long-pass filter RG 590 E, DM 560 A, as well as with side (SSC) and forward (FSC) scatters. Histograms were analysed using a FloMax (Partec GmbH, Münster, Germany) software. Coefficient of variation (CV) of $\mathrm{G}_{0} / \mathrm{G}_{1}$ peak of $C$. orbicularis ranged between 2.97 and 5.58. Nuclear DNA content was calculated using the linear relationship between the ratio of the $2 \mathrm{C}$ peak positions Cotoneaster/ Petunia on a histogram of fluorescence intensities.
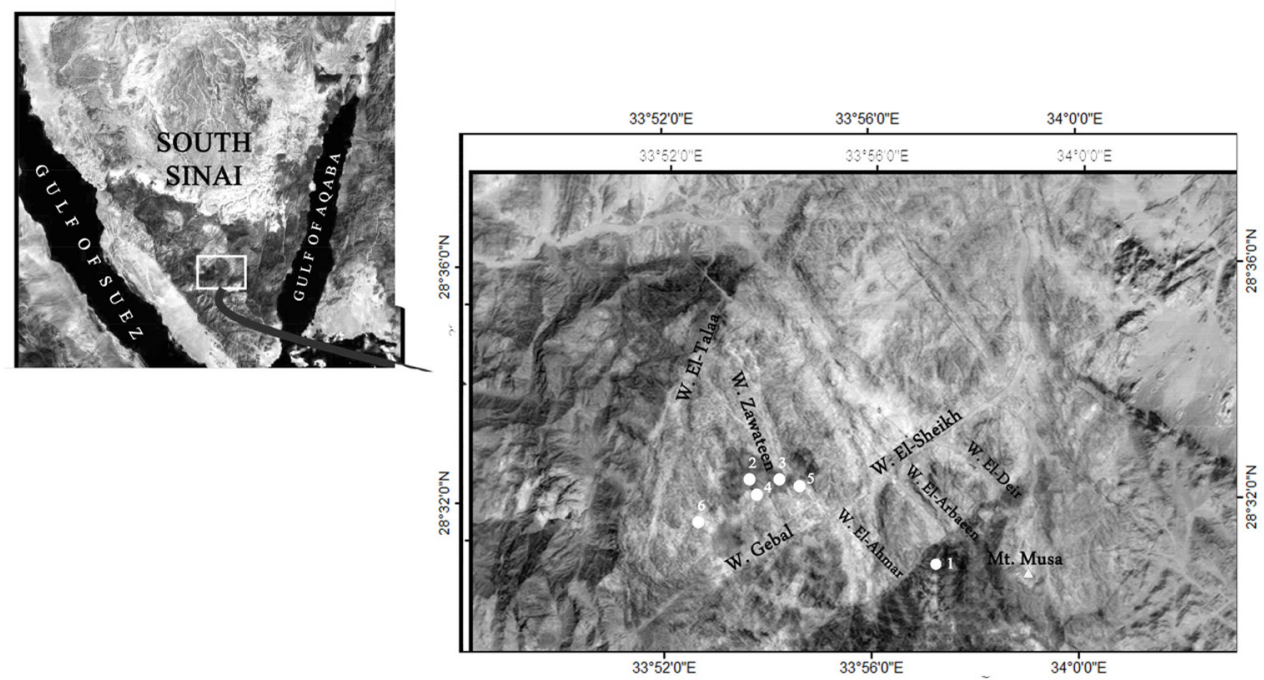

Fig.1. Locations of the six known populations of Cotoneaster orbicularis in St. Catherine, Egypt protectorate. 1 ShaMo (Shqif Shobak, Wadi Shaq Mousa), 2 - UL (Gebel Um Louz), 3 - AQ (Al Qalaa), 4 - NU (Nehaza Um Louz), 5 - SAS (Shqif Abu Shawht), 6 - WM (Wadi Mezah) 
TABLE 1. Measures of genetic variation and Hardy-Weinberg equilibrium in the six extant populations of Cotoneaster orbicularis.

\begin{tabular}{|c|c|c|c|c|c|c|}
\hline Population & Locus & $A$ & $H_{o}$ & $H_{e}$ & $F$ & $P$ \\
\hline \multirow[t]{7}{*}{ ShaMo } & Cor36 & 3 & 0 & 0.620 & 1 & $0.000^{\prime}$ \\
\hline & Cor40 & 2 & 0 & 0.420 & 1 & $0.002^{* * *}$ \\
\hline & Cor42 & 1 & 0 & 0 & - & \\
\hline & Cor44 & 2 & 1 & 0.375 & 0.822 & $0.020^{*}$ \\
\hline & Cor53 & 1 & 0 & 0 & - & \\
\hline & Cor54 & 1 & 0 & 0 & - & \\
\hline & Mean \pm SD & $1.667 \pm 0.333$ & & $0.236 \pm 0.111$ & & \\
\hline \multirow[t]{7}{*}{ UL } & Cor36 & 2 & 0 & 0.180 & 1 & $0.002^{* *}$ \\
\hline & Cor40 & 2 & 0 & 0.420 & 1 & $0.002^{* *}$ \\
\hline & Cor42 & 1 & 0 & 0 & - & \\
\hline & Cor44 & 2 & 0.083 & 0.095 & -0.053 & $0.868^{\mathrm{ns}}$ \\
\hline & Cor53 & 1 & 0 & 0 & - & \\
\hline & Cor54 & 1 & 1 & 0 & - & \\
\hline & Mean \pm SD & $1.500 \pm 0.224$ & & $0.116 \pm 0.068$ & & \\
\hline \multirow[t]{7}{*}{$\mathbf{A Q}$} & Cor36 & 2 & 0 & 0.180 & 1 & $0.002^{* *}$ \\
\hline & Cor40 & 1 & 0 & 0 & - & \\
\hline & Cor42 & 1 & 0 & 0 & - & \\
\hline & Cor44 & 1 & 0 & 0 & - & \\
\hline & Cor53 & 1 & 0 & 0 & - & \\
\hline & Cor54 & 1 & 0 & 0 & - & \\
\hline & Mean $\pm \mathrm{SD}$ & $1.167 \pm 0.408$ & & $0.030 \pm 0.030$ & & \\
\hline \multirow[t]{7}{*}{ NUL } & Cor36 & 2 & 0 & 0.500 & 1 & $0.002^{* *}$ \\
\hline & Cor40 & 1 & 0 & 0 & - & \\
\hline & Cor42 & 1 & 0 & 0 & - & \\
\hline & Cor44 & 1 & 0 & 0 & - & \\
\hline & Cor53 & 1 & 0 & 0 & - & \\
\hline & Cor54 & 2 & 0 & 0.320 & 1 & $0.002^{* *}$ \\
\hline & Mean \pm SD & $1.330 \pm 0.211$ & & $0.137 \pm 0.090$ & & \\
\hline \multirow[t]{4}{*}{ SAS } & Cor36 & 1 & 0 & 0 & & \\
\hline & Cor40 & 1 & 0 & 0 & & \\
\hline & Cor42 & 1 & 0 & 0 & & \\
\hline & Cor44 & 3 & 0 & 0.660 & 0 & $0.000^{* * *}$ \\
\hline
\end{tabular}




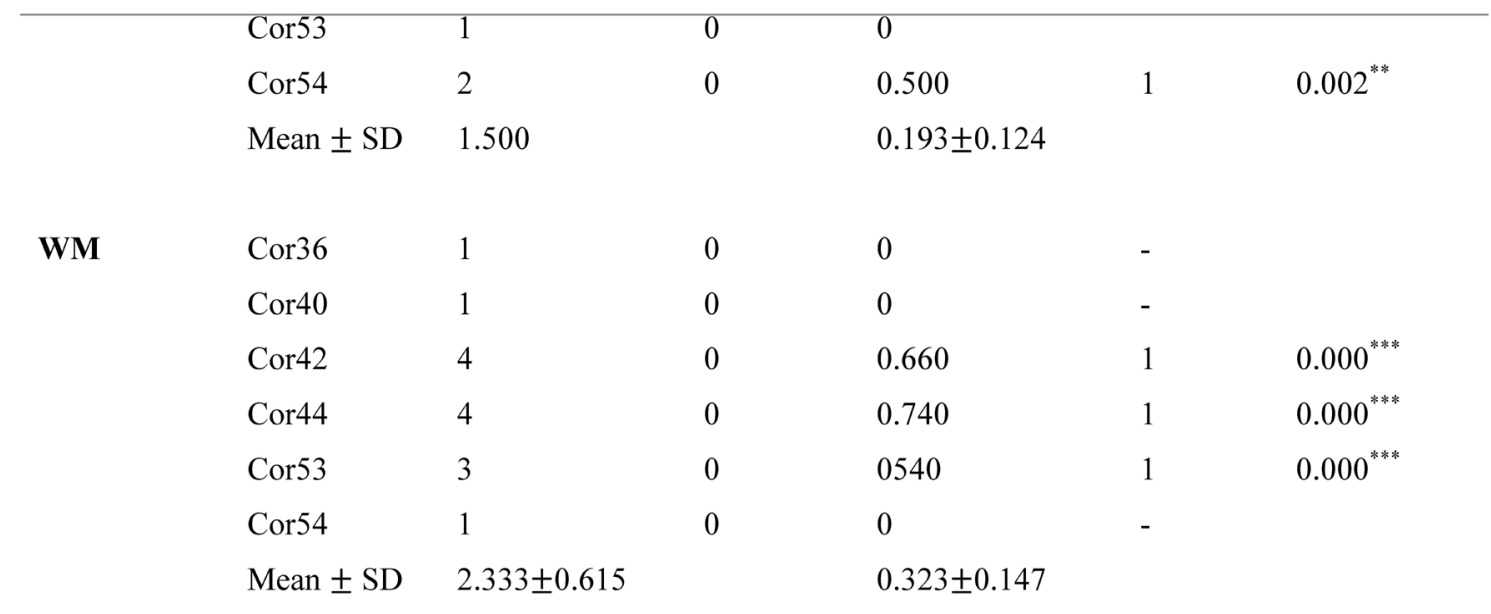

A- number of alleles, Ho - observed heterozygosity, He - expected heterozygosity, F - Wright's fixation index, ns - not significant, $* \mathrm{P}<0.05, * * \mathrm{P}<0.01, * * * \mathrm{P}<0.001)$. All values were calculated for 10 individuals per population.

\section{Results and Discussion}

Genetic variability and genetic structure of populations

The largest size population: UL, revealed polymorphism at three out of six tested microsatellite loci. The populations with an intermediate size, AQ, NUL, SAS, and WM were polymorphic for one, two, two, and three loci, respectively, whereas the smallest population, ShaMo, contained three polymorphic loci (Table 1). The percentage of polymorphic loci were $50 \%$ in ShaMo, UL, and WM populations, $33.33 \%$ in
NUL and SAS populations, $16.67 \%$ in AQ population. The highest mean number of alleles per locus $\mathrm{Na}$ was 2.33 (WM population), whereas the lowest 1.17 (AQ population; Table 1). The means of effective number of alleles per locus Ne, Shannon's Index I, and expected heterozygosity $H_{e}$ ranged between 1.03 , $0.054,0.030$ in AQ population and 1.994, 0.581, 0.323 in WM population, respectively (Fig. 2). The mean of private number of alleles per locus varied between 0 in NUL and AQ populations and 1.333 in WM population. Total heterozygosity, averaged over all loci and populations, was $H_{T}=0.464$.

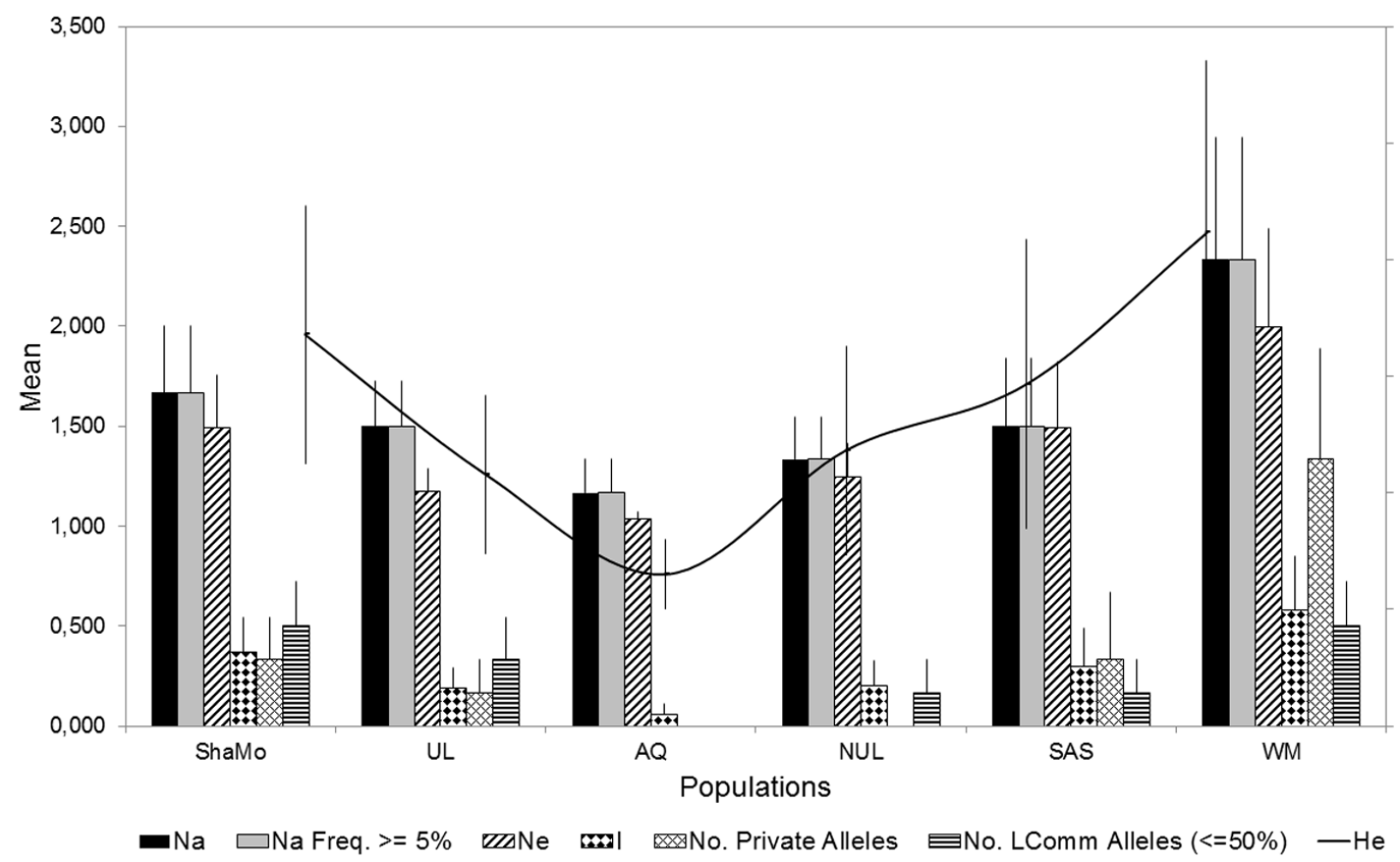

Fig. 2 Allelic patterns of six loci across the studied populations of Cotoneaster orbicularis. 
TABLE 2. Analysis of molecular variance (AMOVA) for populations of $C$. orbicularis based on data from six microsatellite loci.

\begin{tabular}{lccccc}
\hline Source & Sum of & Mean & Estimated & \\
squares & squares & variance & Percentage \\
\hline Among Populations & 5 & 105.008 & 21.002 & 0.994 & $64 \%$ \\
Among Individuals within populations & 54 & 62.100 & 1.148 & 0.574 & $36 \%$ \\
Total & 59 & 167.108 & & 1.568 & $100 \%$ \\
\hline
\end{tabular}

Analysis of six polymorphic loci, considering low values of mean number of alleles per locus $\mathrm{Na}$, means of effective number of alleles per locus Ne, Shannon's Index I, expected heterozygosity He, and the total genetic diversity of $C$. orbicularis, have been revealed very low genetic variation in all populations of C. orbicularis. Similarly, low genetic diversity has been previously reported for populations of $C$. orbicularis (Mansour et al., 2016) as well as other isolated and endemic species (e.g. Hamrick \& Godt, 1989; Hamrick et al., 1992; Crowford et al., 2011 and Hirai et al., 2012).

Genetic variation in general, and, specifically, in rare Cotoneaster species, can be influenced by reproductive systems. For instance, C. schantungensis, endemic to China, exhibits considerable gene flow among its populations, and consequently has a high genetic diversity (Ma et al., 2015), whereas the two apomictic populations of C. wilsonii, endemic to South Korea, exhibit low genetic diversity (Park et al., 2009). Thus, the present results suggest apomictic reproduction in $C$. orbicularis.

Reduced genetic diversity can be a result of genetic drift and inbreeding in species with limited and declining population size (Blomqvist et al., 2010; Jacquemyn et al., 2010 and Smyser et al., 2012). Random loss of alleles and thus the low genetic variation observed in this study could be due to the severe reduction of population size observed in C. orbicularis especially in the last few decades; the number of individuals varied between 14 and 38 .

On the other hand, high genetic differentiation was observed among the studied $C$. orbicularis populations (FST $=$ 0.634 , RST $=0.889$ ). The results of AMOVA (Table 2) confirmed that the greatest genetic differentiation existed among populations $(64 \%, \mathrm{P}=0.010)$, while it was much lower among individuals within populations $(36 \%, \mathrm{P}$ $=0.010)$. These high measures of differentiation among populations coincided with very low gene flow between populations $(\mathrm{Nm}=0.142)$. Moreover, the limited distribution area of $C$. orbicularis resulted in only two to five alleles scored per locus (Table 1). These results are in agreement with the pattern for elevated genetic differentiation between populations of some other rare species (Hamrick \& Godt, 1989 and Hamrick et al., 1992), including another plant taxa in the South Sinai region (Wolff et al., 1997; Zaghloul et al., 2012 and Jimenez et al., 2014).

Low seed dispersal in C. orbicularis could be the main reason for the low gene flow among populations. Indeed, seed dispersal has been described to be imperfect in Cotoneaster species because of the seed size and characteristic fruit, which fall close to the mother plant (Pritchard et al., 2014). Seeds of C. orbicularis lack any obvious adaptations for wind-driven dispersal and are likely being dispersed by birds and small mammals. This limits seed dispersal at high elevated mountains sites. Thus, the main source of gene flow is pollen flow, observed in other Cotoneaster species, especially in those that are diploid and undergo sexual reproduction (Hylmö \& Fryer, 1999). However, natural fragmentation of the habitat of $C$. orbicularis, as well as the remarkably sharp topography of the St. Catherine Protectorate, are most likely the reasons confining pollinator abundance. This can explain the presence of numerous empty seeds produced.

The migration rate found here in $C$. orbicularis $(\mathrm{Nm}=0.142)$ was much lower than the value properly required to cease genetic drift (Spieth, 1974). Therefore, genetic drift, in addition to low gene flow, could result in an added reduction of genetic diversity in the populations of $C$. orbicularis. 
TABLE 3. Nuclear DNA content (pg/2C $\pm \mathrm{SD})$ in three populations of Cotoneaster orbicularis grown in Mount St. Catherine, Egypt, estimated by flow cytometry ( $n$ - number of analysed seeds)

\begin{tabular}{lcccc}
\hline & \multicolumn{4}{c}{ Nuclear DNA content } \\
\cline { 2 - 5 } Population & $\mathbf{n}$ & Diploid & $\mathbf{n}$ & Tetraploid \\
\hline ShoMo & 1 & 1.954 & 1 & 3.881 \\
UL & 10 & $1.926 \pm 0.045$ & 5 & $3.774 \pm 0.087$ \\
WM & 17 & $1.911 \pm 0.018$ & 3 & $3.789 \pm 0.015$ \\
Mean & 28 & $1.918 \pm 0.031$ & 9 & $3.778 \pm 0.082$ \\
\hline
\end{tabular}

\section{Mating system of $C$. orbicularis}

All loci, except Cor44 in the UL population, significantly departed from Hardy-Weinberg equilibrium because of heterozygote deficiency, as demonstrated by the positive values of the fixation index $\mathrm{F}$, which ranged from 0.822 to 1.000 (Table 1) and averaged 0.906 across all loci and populations. The multilocus outcrossing rate $\left(t_{m}\right)$ estimates are $1.200( \pm 0.002, \mathrm{SE})$ in Sha Mo, NUL, SAS and WM populations, $1.155( \pm 0.000$, $\mathrm{SE})$ in UL population and $0.001( \pm 0.000, \mathrm{SE})$ in AQ population, whereas the population singlelocus outcrossing rates $\left(t_{s}\right)$ are $1.200( \pm 0.002, \mathrm{SE})$ in ShaMo, NUL, and SAS, $1.174( \pm 0.001, \mathrm{SE})$ in $\mathrm{UL}, 1.136( \pm 0.000, \mathrm{SE})$ in WM population and $0.001( \pm 0.000, \mathrm{SE})$ in AQ population. Values of $\left(t_{m}-t_{s}\right)$ are equal to zero in five populations and 0.064 in WM.

The majority of Cotoneaster species are obligately apomictic (Hylmö \& Fryer, 1999). Sexual reproduction exists in some diploid species. In the Alps and Pyrenees, Favarger $(1969,1971)$ found diploid as well as tetraploid specimens of Cotoneaster integerrimus sensu lato. The present results indicate that $C$. orbicularis is heavily apomictic, with an average value of Wright's, (1943) fixation index $F=0.906$, reflecting a pronounced deficit of heterozygotes. Inbreeding in self-compatible plants, such as $C$. orbicularis, may be autonomous (i.e., without pollinator assistance) or induced by foraging pollinators, and/ or by crossing between related individuals (i.e., biparental inbreeding). We detected low biparental inbreeding only in WM $\left(t_{m}-t_{s}=0.064\right)$, suggesting that some degree of cross-fertilization between individuals that share the same alleles occurs in this population, but not in the other five populations. Therefore, it seems that gametes transfer between individuals within populations are very limited, most likely due to infrequent pollinator services.
Therefore, diploid individuals escaped loss of genetic variation delaying its extinction due to the polyploidy that is exhibited by individuals with a tetraploid genome. The high inbreeding coefficient detected by our analyses, then, can be better explained by recurring apomixes in $C$. orbicularis.

\section{Nuclear DNA content}

Flow cytometric estimation of nuclear DNA of species belonging to the family Rosaceae family is rather challenging because of the presence in the leaf cytosol of phenolic compounds, which are well known inhibitors of PI staining (Jedrzejczyk \& Sliwinska, 2010). Seeds of Cotoneaster species are free of these inhibitors and therefore were used in the present experiment. Flow cytometric estimation of nuclear DNA content revealed that most of the embryos possess about $1.9 \mathrm{pg} / 2 \mathrm{C}$ DNA (Table 3). However, in each population also some embryos with double the amount of DNA, $3.8 \mathrm{pg} / 2 \mathrm{C}$, occurred. There were some differences in genome sizes between populations; genome size of ShaMo appeared to be higher than that of the two other populations. However, because only single seeds were available for this population it was not possible to perform statistical analyses to estimate the significance of those differences.

Genome size has been estimated previously only for six Cotoneaster species, and 2C ranged between 1.41 and 2.77 pg (Dickson et al., 1992 and Jedrzejczyk \& Sliwinska, 2010). Since the previously estimated haploid genome size for this genus is 0.7 pg, present estimations for $C$. orbicularis, $1.92 \mathrm{pg} / 2 \mathrm{C}$ and $3.78 \mathrm{pg} / 2 \mathrm{C}$, correspond to diploid and tetraploid chromosome numbers, respectively. The presence of tetraploid embryos confirmed that in some cases apomixis occurred in the studied populations (Hylmö $\&$ Fryer, 1999). To our best knowledge those are the first estimations of the nuclear DNA content of $C$. orbicularis. 


\section{Conclusion and Recommendations}

This study provides the first molecular assessment of genetic variability, genetic structure, and mating systems for the surviving populations of $C$. orbicularis using SSR loci. The results reveal exceptionally low genetic diversity, high inbreeding, and high genetic differentiation among populations. The estimation of nuclear DNA content reveals the presence of diploid and tetraploid chromosome numbers, existence of tetraploid individuals indicating the presence of apomixes in populations of $C$. orbicularis.

The low genetic variation and high level of inbreeding are the main threats to the existence of the remaining wild populations of $C$. orbicularis, likely caused by aridification-mediated, demographic reduction (Keller \& Waller, 2002; Vilas et al., 2005 and Frankham, 2005) even in predominantly self-fertilizing populations (Husband \& Schemske, 1996). To guarantee the conservation of $C$. orbicularis in the short and long term there should be a focus on habitat preservation and restoration, including a careful management of water resources and restriction of grazing in the region. Given the rarity of this species and the high genetic differentiation among its populations, these measures should be complemented by a thorough sampling of seeds from as many populations and individuals as possible (Holsinger \& Gottlieb, 1991). Some of these seeds should be incorporated into a germplasm bank for long-term, exsitu conservation and eventual population reinforcement and reintroduction, and other seeds should be used to implement a breeding program aimed at determining the consequences of inbreeding depression in C. orbicularis.

Since among the seeds, even originated from the same population, individuals of different ploidy can occur, the ploidy of the plants should be checked before using them in a breeding program.

Acknowledgments: The authors thank Professors Elsayeda Gamal-Eldin and Wafaa Kamel (University of Suez Canal, Egypt) for providing valuable information on the taxonomy and the locations of Cotoneaster orbicularis in South Sinai Mountains, and Professor J.D. Bewley (University of Guelph, Canada) for critical comments on the manuscript. This study was supported by the Science and Technology
Development Fund STDF grant 6083 to H.M.

\section{References}

Arif, I.A., Khan, H.A., Shobrak, M., Al homaidan, A.A., Al sadoon, M., Al farhan, A.H. and Bahkali, A.H. (2010) Interpretation of electrophoretograms of seven microsatellite loci to determine the genetic diversity of the Arabian Oryx. Genet Mol. Res. 9,259-265

Barton, N.H. and Slatkin, M. (1986) A quasiequilibrium theory of the distribution of rare alleles in a subdivided population. Heredity, 56,409-415.

Boulos, L. (1983). "Medicinal plants of North Africa". Algonac, Michigan: Reference Publications.

Blomqvist, D., Pauliny, A., Larsson, M. and Flodin, L.A. (2010) Trapped in the extinction vortex? Strong genetic effects in a declining vertebrate population. BMC Evol. Biol. 10,33.

Crowford, D.J., Ruiz, E., Stuessy, T.F., Tepe, E., Aqeveque, P., Gonzalez, F., Jensen, R.J., Anderson, G.J., Bernardello, G., Baeza, C.M., Swenson, U. and Silva, M. (2011) Allozyme diversity in endemic flowering plant species of the Juan Fernandez Archipelago, Chile: Ecological and historical factors with implications for conservation. Am. J. Bot. 88,2195-2203.

Dickoré, W.B. and Kasperek, G. (2010) Species of Cotoneaster (rosaceae, maloideae) indigenous to, naturalising or commonly cultivated in Central Europe. Willdenowia, 40,13-45.

Dickson, E.E., Arumuganathan, K., Kresovich and S., Doyle, J.J. (1992) Nuclear DNA content variation within the rosaceae. Am. J. Bot. 79,1081-1086.

El Hadidi, M.N., Batanouny, K.H. and Fahmy, A.G. (1991) "The Egyptian Plant Red Data Book": Volume 1 Trees and Shrubs. The Palm Press, Cairo, Egypt.

El-Mousallamy, A.M.D., Hussein, S.A.M., Merfort, I. and Nawwar, M.A.M. (2000) Unusual phenolic glycosides from Cotoneaster orbicularis. Phytochemistry, 53, 699-704.

Excoffier, L., Smouse, P.E. and Quattro, J.M. (1992) Analysis of molecular variance inferred from metric distances among DNA haplotypes: application to human mitochondrial DNA restriction data. Genetics, 131,479-491.

Favarger, C. (1969) Notes de caryologie Alpine V. Bull. Soc. Neuchat. Sci. Nat. 92,13-30.

Favarger, C. (1971) Relation entre de la flore 
méditerranéenne et celle des enclaves à végétation subméditerranéenne d'Europe centrale. Boissiera, 19,149-168.

Frankham, R. (2005) Genetics and extinction. Biol. Cons. 126,131-140.

Frankham. R., Ballou, J.D. and Briscoe, D.A. (2002) "Introduction to Conservation Genetics."Cambridge University Press, Cambridge.

Galbraith, D.W., Harkins, K.R., Maddox, J.M., Ayres, N.M., Sharma, D.P. and Firoozabady, E. (1983) Rapid flow cytometric analysis of the cell cycle in intact plant tissues. Science, 220,1049-1051.

Giorgi, F. and Lionello, P. (2008) Climate change projections for the Mediterranean region. Global Planet Change, 63,90-104.

Grainger, J. (2003) People are living in the park. Linking biodiversity conservation to community development in the Middle East region: a case study from the Saint Katherine Protectorate, Southern Sinai. J. Arid Environ. 54,29-38.

Hamrick, J.L. and Godt, M.J.W. (1989) Allozyme diversity in plant species. In: " Plant Population Genetics, Breeding and Genetic Resources "Brown A.H.D., Clegg, M.T., Kahler, A.L., Weir,B.S. (Ed.), pp 42-63. Sinauer Associates, Sunderland.

Hamrick, J.L., Godt, M.J.W. and Sherman-Broyles, S.L. (1992) Factors influencing levels of genetic diversity in woody plant species. New For. 6,95-124.

Hansson, B. and Westerberg, L. (2002) On the correlation between heterozygosity and fitness in natural populations. Mol. Ecol. 11,2467-2474.

Heller, N.E. and Zavaleta, E.S. (2009) Biodiversity management in the face of climate change: a review of 22 years of recommendations. Biol. Conserv. 142,14-32.

Hirai, M., Kubo, N., Ohsako, T. and Utsumi, T. (2012) Genetic diversity in the endangered coastal violet Viola grayi Franchet et Savatier (Violaceae) and its genetic relationship to the species in subsection Rostratae. Conserv. Genet. 13,837-848.

Holsinger, K.E. and Gottlieb, L.D. (1991) Conservation of rare and endangered plants: principles and prospects. In: " Genetics and Conservation of Rare Plants" Falk, D.A., Holsinger, K.E. (Ed.). pp 195208. Oxford University Press, New York.

Husband, B.C. and Schemske, D.W. (1996) Evolution of the magnitude and timing of inbreeding depression in plants. Evolution, 50,54-70.
Hylmö, B. and Fryer, J. (1999) Cotoneasters in Europe. Acta Bota Fenn. 162,179-184.

Issar, A.S. (2008) The impact of global warming on the water resources of the Middle East: past, present and future. In:" Climate Changes and Water Resources in the Middle East and North Africa" Zereini F, Hötzl, H. (Ed.). pp 145-164, Springer, Heidelberg,

Jacquemyn, H., Roldán-Ruiz, I. and Honnay, O. (2010) Evidence for demographic bottlenecks and limited gene flow leading to low genetic diversity in a rare thistle. Cons. Genet. 11,1979-1987.

Jedrzejczyk, I. and Sliwinska, E. (2010) Leaves and seeds as materials for flow cytometric estimation of the genome size of 11 Rosaceae woody species containing DNA-staining inhibitors. $J$ Bot. 2010: Article ID 930895.

Jimenez, A., Mansour, H., Keller, B. and Conti, E. (2014) Low genetic diversity and a high level of inbreeding in the Sinai primrose (Primula boveana), a species on the brink of extinction. Plant Syst. Evol. 300,1199-1208.

Jump, A.S., Marchant, R., Peñuelas, J. (2009) Environmental change and the option value of genetic diversity. Trends Plant Sci. 14,51-58.

Keller. L.F. and Waller, D.M. (2002) Inbreeding effects in wild populations. Trends Ecol. Evol. 17,230-241.

Ma, Y., Qu, S., Xu, X., Liang, T. and Zang, D. (2015) Genetic Diversity Analysis of Cotoneaster schantungensis Klotz using SRAP marker. Am. J. Plant Sci. 6,28602866.

Mansour, H., Bryngelsson, T. and Gustavesson, L. (2016) Development, characterization and transferability of 10 novel microsatellite markers in Cotoneaster orbicularis Schltdl (Rosaceae). J. Genet. DOI: 10.1007/s12041-016-0687-1

Mansour, H., Jimenez, A., Keller, B., Nowak, M. and Conti, E. (2013) Development of 13 microsatellite markers in the endangered Sinai primrose (Primula boveana, Primulaceae). Appl. Plant Sci. 1(6),1200515. 2013 doi: http://dx.doi.org/10.3732/apps.1200515.

Marie, D., Brown, S.C. (1993) A cytometric exercise in plant histograms, with $2 \mathrm{C}$ values for 70 species. Biol. Cell, 78,41-51.

Michalakis, Y. and Excoffier, L. (1996)Ageneric estimation of population subdivision using distances between alleles with special reference for microsatellite loci. Genetics, 142,1061-1064.

Nei, M. (1973) Analysis of gene diversity in subdivided populations. Proc. Natl. Acad. Sci. USA, 70, pp.33213323. 
Park, J.W., Lee, J.S., So, S.K. and Kim, M.Y. (2009) Genetic variation and conservation of the endangered species Cotoneaster wilsonii (Rosaceae) from Ulleung Island. Kor. J. Plant Tax. 39,125-129.

Peakall, R. and Smouse, P.E. (2006) GENALEX 6: genetic analysis in Excel. Population genetic software for teaching and research. Mol. Ecol. Notes, 6,288-295.

Pritchard, H.W., Moat, J.F., Ferraz, J.B.S., Marks, J.B.S., Camargo, J.L.C., Nadarajan, J. and Ferraz, I.D.K. (2014) Innovative approaches to the preservation of forest trees. Forest Ecol. Manag. 333,88-98.

Ritland, K. and Jain, S.K. (1981) A model for the estimation of outcrossing rate and gene frequencies using independent loci. Heredity, 47,35-52.

Ritland, K. (2002) Extensions of models for the estimation of mating systems using $\mathrm{n}$ independent loci. Heredity, $\mathbf{8 8 , 2 2 1 - 2 2 8 . ~}$

Ritland, K. (2004) Multilocus mating system program MLTR version 3.0. University of British Colombia. $\mathrm{http}: / /$ genetics.forestry.ubc.ca/ritland/programs.html. Accessed 3 December 2007.

Slatkin, M. (1995) A measure of population subdivision based on microsatellite allele frequencies. Genetics, 139,457-462.
Smyser, T.J., Duchamp, J.E., Johnson, S.A., Larkin, J.L. and Rhodes Jr, O.E. (2012) Consequences of metapopulation collapse: comparison of genetic attributes between two Allegheny woodrat metapopulations. Conserv. Genet. 13,849-58.

Spieth, P.T. (1974) Gene flow and genetic differentiation. Genetics 78,961-965.

Vilas, C., San Miguel, E., Amaro, R. and García, C. (2005) Relative contribution of inbreeding depression and eroded adaptive diversity to extinction risk in small populations of shore campion. Conserv. Biol. 20,229238.

Weir, B.S. and Cockerham, C.C. (1984) Estimating F-statistics for the analysis of population structure. Evolution, 38,1358-1370.

Wolff, K., El-Akkad, S. and Abbot, R.J. (1997) Population substructure in Alkanna orientalis (Boraginaceae) in the Sinai Desert, in relation to its pollinator behaviour. Mol. Ecol. 6,365-372.

Wright, S. (1943) Isolation by distance. Genetics, 28,114138.

Zaghloul, M.S., Hamrick, J.L., Moustafa, A.A.(2012) Conservation genetics of Sinai's remnant populations of Moringa peregrina, an economically valuable medicinal plant. Conserv. Genet. 13,9-19.

Received : $21 / 3 / 2017$

Accepted : $1 / 4 / 2017$ 


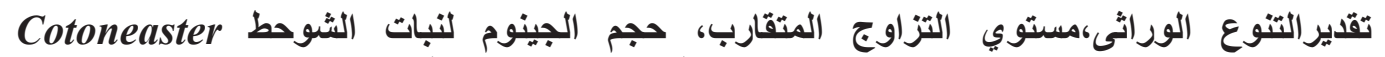
orbicularis Schldt

\footnotetext{
حسن منصور 1,2 و إلويرا سيلوينسكى

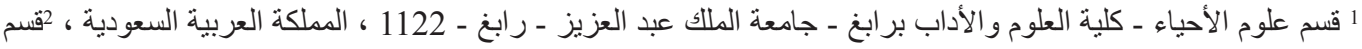

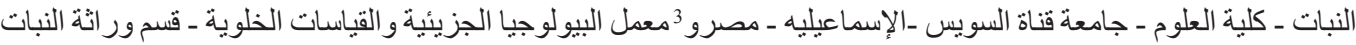
و الفسيولوجى و التقنية الحيوية - جامعة العلوم و التكنولوجيا بيدكوشت - بو لاكو لاندا.
}

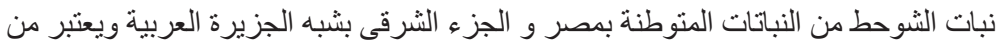

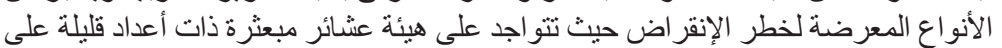

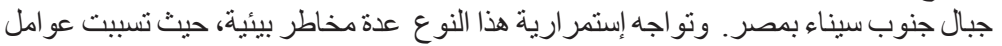

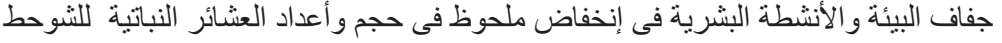

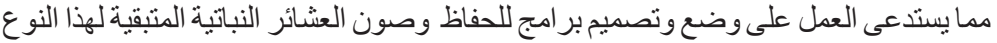

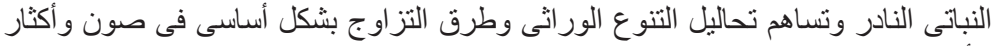

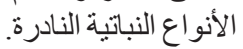

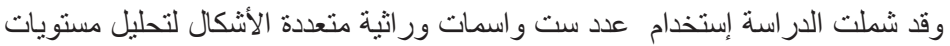
التتوع الور اثىى ومدى تاثير نظام تز اوج الأفر اد المتقاربة على إستمر ارية عشائر نبات الثوحط.

كما إستعملت تقانة التدفق الخلوى فى هذا البحث لأول مرة فى تقيرحجم الجينوم لنبات الثنوحطومن ثم تحديد مستوى الصيغة الصبغية لهذا النوع.

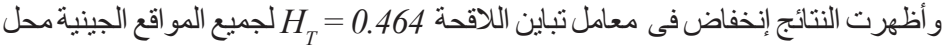
الدراسة، وإرتفاع بمعامل التمايز الور انثى فيما بين العشائر

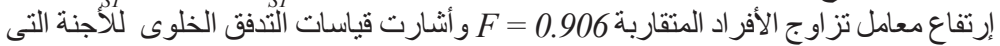

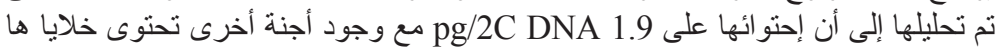

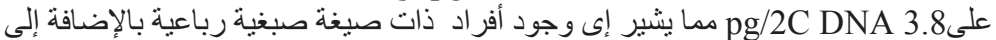
الأفر اد ذات صيغة ثينائة المجمو عة الصبغية.

توفر نتائج الدراسة البيانات الدنطلبة في إدارة وصون عشائر نبات الثوحط ،وكنلك الحفظ خارج الموقع، وذلك لمنع انقر اض هذا النوع النباتى. 